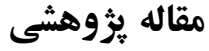 \\ مجله دانشگاه علوم يزشكى رفسنجان

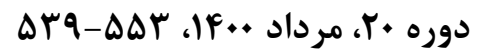 \\ تأثير آموزش شيوه زندكى سالم بر كيفيت زندكى سالمندان شهرستان رفسنجان: يكك مطالعه نيمه تجربى لئ
}

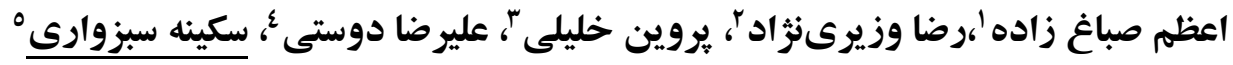

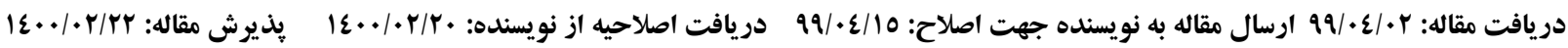

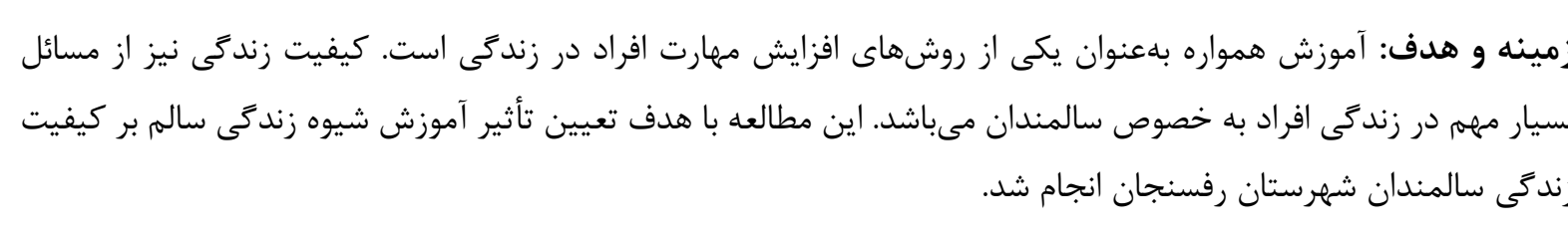

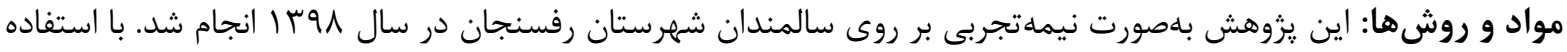
از روش نمونه

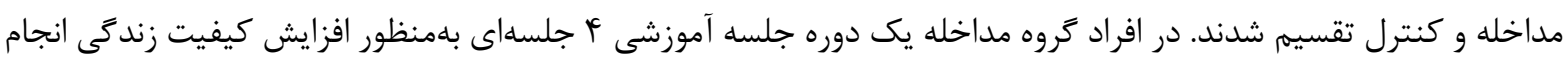

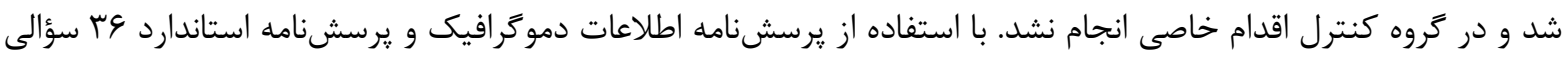

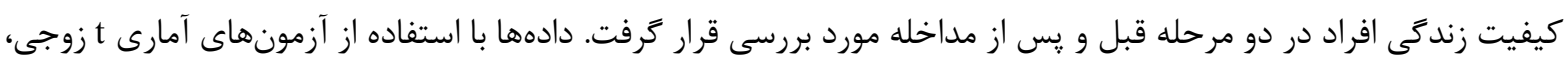

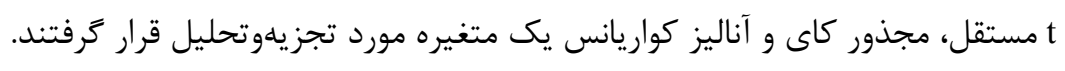

يافتهها: ميانكين و انحراف معيار سنى افراد در كروه مداخله و كنترل به ترتيب هـ/

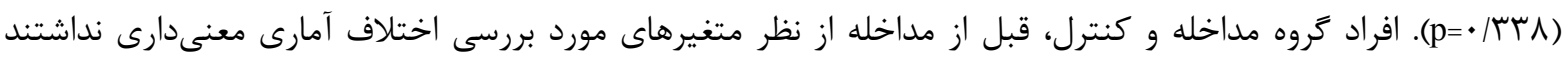

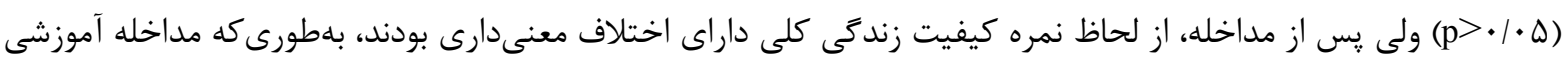

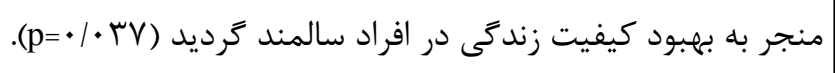
نتيجهَيرى: نتايج يزوهش حاضر نشان داد كه آموزش مىتواند باعث افزايش كيفيت زندگى سالمندان شود. بنابر اين ضرورى

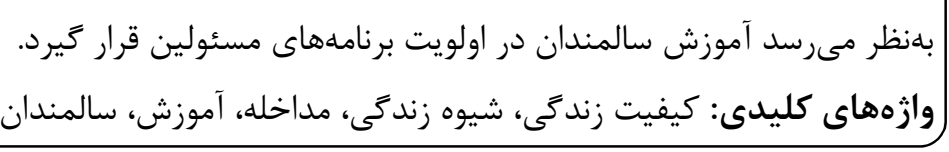

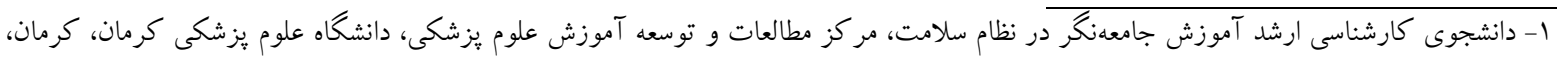

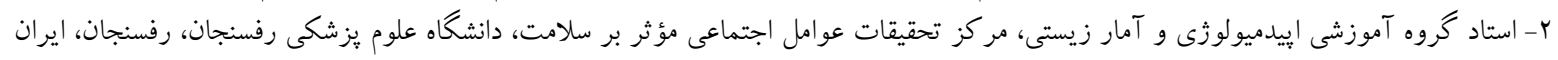

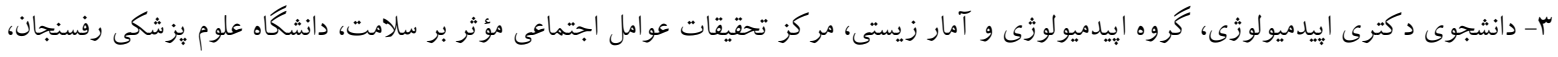

رفسنجان، ايران

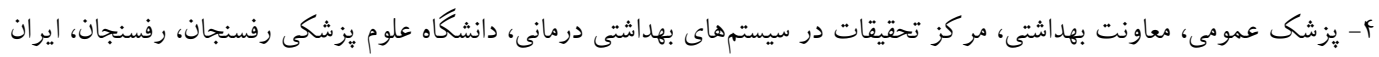

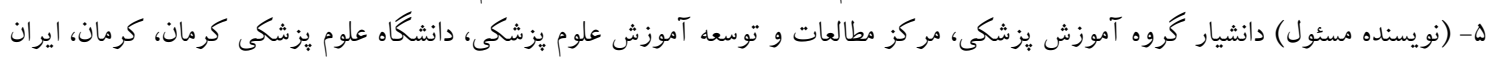

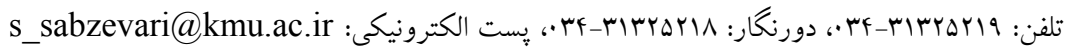


راستا آموزش بهداشت از اهميت ويزهاى برخوردار است و مى

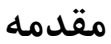
تواند بسيارى از مشكلات ناشى از تغييرات سالمندى را كنترل

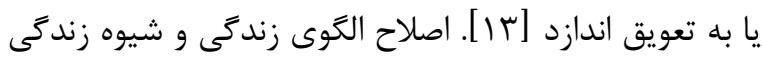
سالم و توجه به كيفيت آن تا حد بسيار زيادى مىتواند باعث افزايش كار آيى و استقلال سالمندان كردد و آنها را در كنترل عوارض متعدد سالمندى و درمآنهاى مختلف آن كمك نمايد [1 [1]]. در اين خصوص سبك زندگى سالم و آموزش در اين زمينه مىتواند باعث حفظ و ارتقاء سطح سلامت و رفاه و

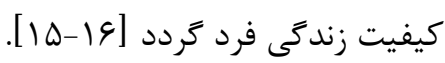
با توجه به مطالب ذكر شده و اهميت دوران سالمندى در جوامع صنعتى امروزى، ضرورت و اهميت برنامهريزى و ارائه آموزشهاى لازم در رابطه با ارتقاء كيفيت زندگى به اين قشر از جامعه از جمله نكات مهم و ضرورى به نظر مىرسد. در همين راستا آموزش بهداشت و شيوه زندگى سالم به سالمندان مىتواند بسيارى از مشكلات ناشى از سالمندى را كنترل كرده و يا به تعويق بياندازد [؟]. بنابر اين، اين مطالعه با هدف تعيين تأثير آموزش شيوه زندگى سالم بر كيفيت زندگى سالمندان شهرستان رفسنجان طراحى و اجرا شده است.

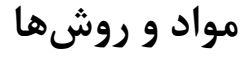

يزوهش حاضر به صورت نيمه تجربى بر روى سالمندان شهرستان رفسنجان در سال ^وبا انجام شد. براساس نتايج مطالعه Khalili و همكاران [IV] با در نظر گرفتن انحراف معيار V/V براى اختلاف ميانگين نمره كيفيت زندگى در دو كروه، مقدار اندازه اثر ه، مقدار آلفاى ه • • و قدرت • • درصد و با در نظر كرفتن •| درصد ريزش، أم نفر از افراد واجد شرايط مراجعه كننده به مراكز خدمات جامع سلامت شهرى و روستايى دانشخاه علوم يزشكى رفسنجان انتخاب شدند. با

يكى از مههمترين جـالشهـاى جهـان امـروز، افزايش جمعيـت سـالمندان است [1]]. برآورد مىشود كه روند صعودى افزايش جمعيت سالمندان ادامه داشته و تا سال

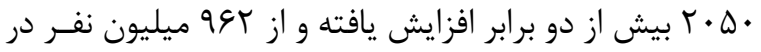

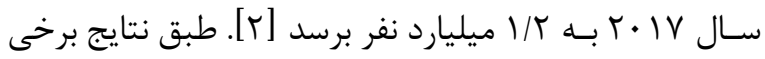

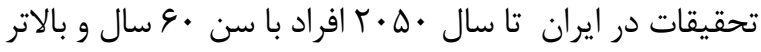
اب درصد جمعيت (تقريباً وج ميليون)، افراد هو سال و بالاتر

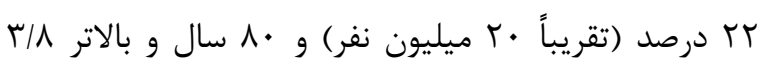
درصد (ه/ץ ميليون نفر) را به خود اختصاص خواهند داد [ب]. يكى از مسائل عمده جمعيتى، پِيامدهاى ناشى از سالمندى است [\&]. با بروز دوران سالمندى، استقلال فردى افراد در انجام امور روزانه از بين مىرود كه به طور مستقيه بر كيفيت زندگى آنها تأثير مى گذارد [ه]]. افراد سالمند با مجموعهاى از مشكلات مرتبط با افزايش سن روبهرو مىباشند كه با اصلاح سبك زند

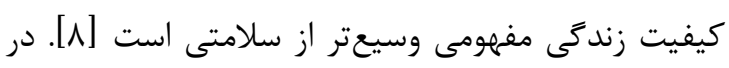
واقع كيفيت زندگى وابسته به سلامتى يك مفهوم خند بعدى

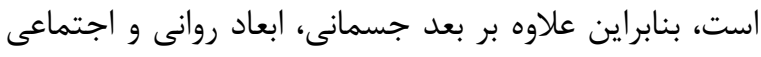

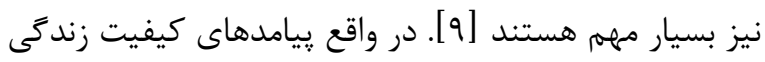
را مىتوان در دو بعد ذهنى و عينى در نظر كرفت [.1]. يافتههاى برخى از مطالعات نشان مىدهد كه مشكلات

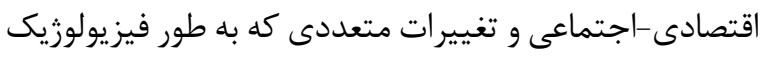
در سنين بالا رخ مىدهد در كاهش كيفيت زندگى سالمندان تأثير دارد [11]]. يكى از عواملى كه ارتباط تنگَاتنكى با كيفيت زندگى در دوران سالمندى دارد سبك زندگى مىباشد [1 I]]. در همين 
نفر •له وارد گروه كنترل شد و همين توالى ادامه دارد؛ به همين ترتيب افراد گروه مداخله و كنترل انتخاب شدند. معيارهاى ورود به مطالعه شامل داشتن سن •9 الى 99 سال، رضايت آكاهانه به شركت در يزوهش، داشتن وضعيت روحى و جسمى مناسب (توانايى ياسخ گويى مناسب به محقق را داشته باشد) بود. افرادى كه سابقه شركت در جلسات آموزشى افزايش كيفيت زندكى را داشتند از مطالعه خارج شدند. اين طرح در كميته اخلاق دانشگاه علوم يزشكى كرمان مورد بررسى و تأييد قرار گرفت (IR.KMU.REC.1398.265). ابزار جمعآورى اطلاعات شامل رسشنامه اطلاعات

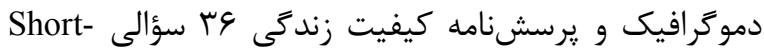
form 36) (questionnaire (SF-36) دموكرافيك شامل اطلاعاتى در خصوص سن، جنسيت، ميزان تحصيلات، مصرف دخانيات، شغل، ميزان در آمد (كه بر اساس خودَزارشى و نظر شخصى فرد، به سه گروه خوب، متوسط و بد تقسيم شد) و سابقه بيمارى زمينهاى ( فشارخون، ديابت و سرطان و غيره) فرد بود يرسشنامه كيفيت زندگى شامل צr سؤال در رابطه با كيفيت زندگى بود. اين يرسشنامه متشكل از هشت بخش است كه شامل اين ابعاد مى باشد، عملكرد جسمى: كه توانايى انجام فعاليتهاى زندگى را در بر مى گيرد (• (آيته)، درد جسمى: كه ميزان درد طى أ هفته كذشته و تداخل آن با فعاليتهاى روزانه را ارزيابى مى كند (r) آيتم)، عملكرد اجتماعى: كه ميزان تأثير مشكلات جسمى و روانى را در انجام فعاليتهاى اجتماعى و ارتباط با خانواده، r) دوستان و ساير افراد جامعه مورد ارزيابى قرار مىدهد آيتم)، سلامت روان: كه احساس افسردگى و اضطراب را مىسنجد (له آيتم)، سلامت عمومى: سلامت عمومى رآ رآ براساس ادراى فرد ارزيابى مى كند (ه آيتم)، نشاط: كه
استفاده از روش تخصيص تصادفى نمونههاى انتخابى به

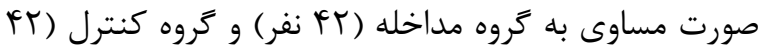

$$
n=\frac{2 \sigma_{d}^{2}\left(Z_{1-\frac{\alpha}{2}}+Z_{1-\beta}\right)^{2}}{\delta^{2}}
$$

افراد با استفاده از نمونهَيرى جند مرحلهاى (نمونهَيرى طبقاى، خوشهاى و تصادفى سيستماتيك) انتخاب شدند. نمونه سكونت سالمندان (شهر يا روستا) و به شيوه متناسب با اندازه با نسبت جنسى برابر انجام شد. بدين (Proportional to size) معنى كه تعداد نمونه سالمندان زن و مرد در شهر و روستا متناسب با تعداد سالمندان شهرى و روستايى بود. نحوه رسيدن به نمونه مورد نظر و انتخاب آنها، با استفاده از نمونه انتخاب خوشه مورد نظر (مركز بهداشتى) از اطلاعات مربوط به مراكز موجود در معاونت بهداشتى استفاده شد و مركز مورد نظر به صورت هدفمند در طبقه مربوطه انتخاب شد. جهت انتخاب سالمندان در هر مركز نيز از روش تصادفى سيتماتيك استفاده شد. با توجه به جمعيت تحت يوشش •و تا 99 ساله در مراكز بهداشتى، كr نفر از مركز شهرى و rr نفر از مركز روستايى جهت ورود به مطالعه گزينش شدند. با استفاده از روش تصادفى سيتماتيك هر · · نفر يك نفر از مركز شهرى و هر · له نفر يك نفر از مركز روستايى انتخاب گرديد. به منظور وارد كردن افراد به دو گروه مداخله و كنترل از روش تخصيص تصادفى سيتماتيك استفاده شد به اين صورت كه نفر اول وارد كروه مداخله و نفر ·r وارد گروه كنترل شد و همين توالى ادامه دارد و براى مركز روستايى، نفر اول وارد گروه مداخله و 
WFT تأثير آموزش شيوه زندگى سالم بر كيفيت زندگى سالمندان ...

آموزش تغذيه توسط كارشناس ارشد تغذيه، آموزش بهداشت روان و ورزشهاى دوران سالمندى توسط كارشناس ارشد روانشناسى و پِيشيرى از يوكى استخوان توسط يزشك عمومى ارائه كرديد و اطلاعات مربوط به شركت كنندكان توسط محقق قبل و يس از مداخله جمع آورى شد. براى گروه كنترل اقدامات روتين انجام گرديد. توضيحات مربوط به طرح درس در انتهاى اين بخش در جدول شماره يك آمده است.

دادهها يس از جمع آورى وارد نرمافزار SPSS نسخه بr شد. براى بررسى تفاوت بين دوگروه از لحاظ متغيرهاى دموكرافيك و نمره كيفيت زندكى قبل از مداخله، از آزمون t مجذور كاى براى متغيرهاى طبقه بندى شده و از آزمون مستقل در صورت برقرارى پِيش فرض نرمال بودن توزيع متغيرها و در صورت برقرار نبودن يِيش فرض نرمال بودن، از معادل نايارامتريك آن (Mann-Whitney U) براى متغيرهاى كمى استفاده شد. براى مقايسه نمره كيفيت زندكى قبل و بعد از مداخله در هر گروه از آزمون t زوجى در صورت برقرارى ييش فرض نرمال بودن (برخوردارى اختلاف ميانگين نمره قبل و بعد در هر گروه از توزيع نرمال) و در صورت برقرار نبودن نرمال بودن، از معادل نايارامتريك آن (آزمون (Wilcoxon كيفيت زندگى در دو گروه با در نظر گرفتن اثر مخدوش كنندكى نمره ميانگين كيفيت زندگى قبل از مداخله، آناليز كوواريانس يك متغيره مورد استفاده قرار گرفتند. نرمال بودن توزيع فراوانى دادهها با استفاده از شاخصهاى جولنى و كشيدگى و همجنين نمودار هيستوگرام ارزيايى شد. در صورتى كه ضريب جولنى مقدارى بين ا- و ا+ و شاخص برآمدكى بين 9/1 - و 99/1+ بود، متغير كمى مورد نظر داراى
محتواى آن در خصوص احساس خالاكى، انرزى و خستگى است (4 آيتم)، مشكلات جسمى: كه نقش محدوديتهايى كه به سبب مشكلات جسمانى ايجاد مىشود را ارزيابى مى كند (4 آيتم) و مشكلات روحى: مشكلات روحى افراد را ارزيابى كند (ץ آيتم) بوده و يك سؤال (سؤال دو) در هيج بعدى مد نظر قرار نمى گيرد. شيوه نمردهى به اين صورت است كه سؤالات

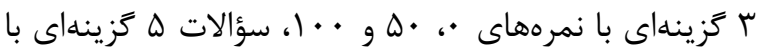

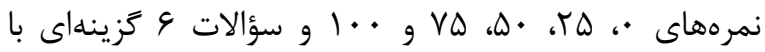

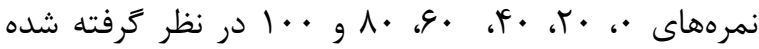
است. در نهايت امتياز فرد در هر بخش محاسبه شد. روايى و

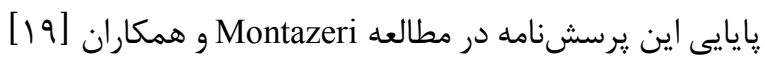
با روش ترجمه مجدد به فارسى برگردانده شده و ضريب يايايى كزارش شده براى خرده مقياسها از VV درصد تا • و درصد مى باشد، به غير از خرده مقياس نشاط كه DQ هرصد كزارش شده است. همرجنين پايايى اين پرسشنامه با آلفاى كرونباخ

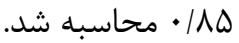

مداخله آموزشى شيوه زندگى سالم طبق راهنماى بهبود شيوه زندگى در دوره سالمندى [·r] طى جهار جلسه براى كروه مداخله اجرا شده است. جهت اجراى برنامه آموزشى و شركت سالمندان تروه مداخله در جلسات آموزشى به وسيله تماس تلفنى با تك تك آنها و ذكر ساعت و مدت حضور در كلاس هماهنكَى لازم با آنها به عمل آمد. براى گروه مداخله، از طريق f جلسه ه\& دقيقهاى در مراكز خدمات جامع سلامت شهرستان رفسنجان به روش سخنرانى و ارائه ياوريوينت، بحث گروهى، ارائه عكس و نمايش فيلم و يرسش و پاسخ آموزش داده شد. سيس سه ماه بعد از اتمام مداخلات آموزشى مجدداً يرسشنامهها براى ارزيابى تأثير آموزش در اختيار نمونههاى يزوهش قرار كرفت و اطلاعات مربوطه جمعآورى شد. 
توزيع نرمال در نظر گرفته مىشد. براى بررسى پِيش فرض همخنى واريانس ها نيز از آزمون Levene استفاده گرديد. سطح معنى دارى در آزمونها هـ • • در نظر گرفته شد.

جلدول | - طرح دوس محتواى آموزشى ارائه شده به سالمندان

\begin{tabular}{|c|c|c|c|c|}
\hline |رسانه آموزشى | رسمى & روش آموزشى & موضوعات آموزشى & هدف كلى & جلسه \\
\hline واسلايد، بردف، عكسه از & و ياسخر و و يرسش & 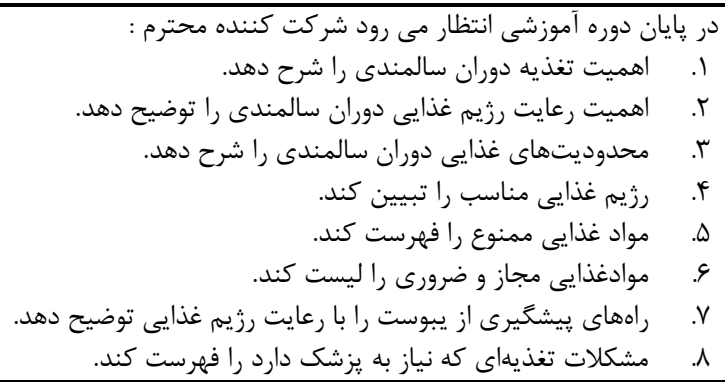 & 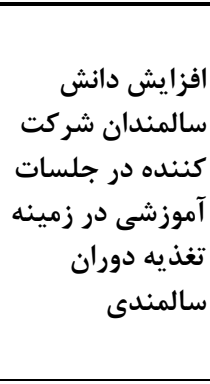 & اول \\
\hline 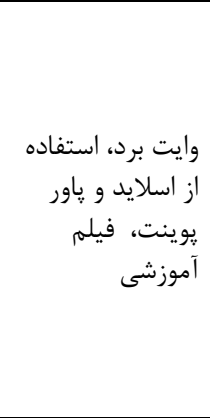 & ياسخ & 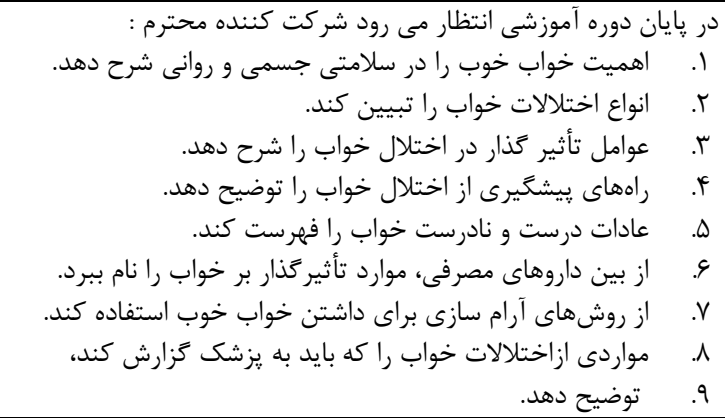 & 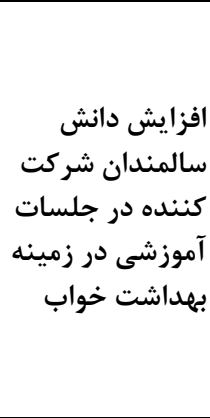 & 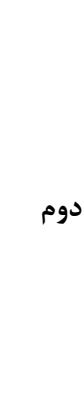 \\
\hline واسلايد، برد، عكس و و & و ياسخخ & 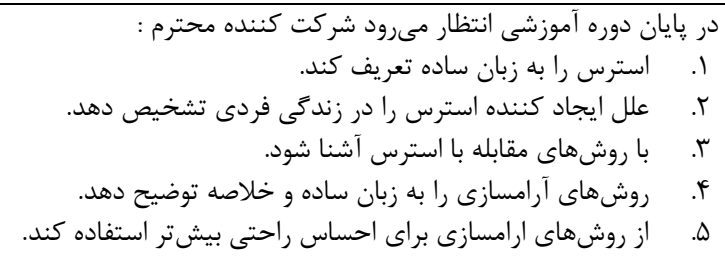 & ساسترس به زباديان & 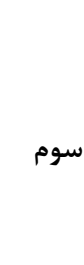 \\
\hline وايت برد، اسلايد & و ياسخرانى، برسش & 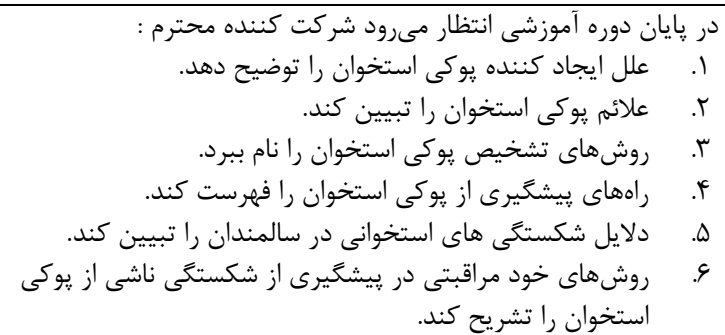 & 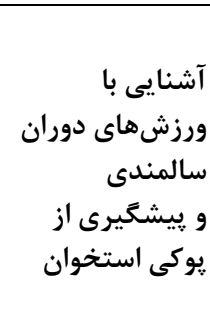 & جهارم \\
\hline
\end{tabular}

در اين مطالعه NF نفر از سالمندان واجد شرايط مورد

بررسى قرار كرفتند. از نظر آمارى تفاوت معنىدارى بين دو

كروه از لحاظ شغل، وضعيت تأهل، وضعيت تحصيلات و 
DFF تأثير آموزش شيوه زندگى سالم بر كيفيت زندگى سالمندان ...

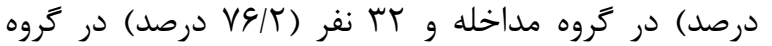

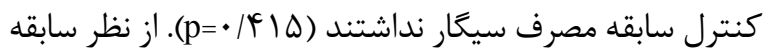

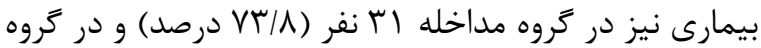
كنترل وץ نفر (99 درصد) سابقه بيمارى داشتند كه از نظر اين متغير اختلاف بين دو گروه معنىدار نبود (p

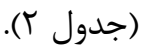

وضعيت اقتصادى اجتماعى مشاهده نشد (ه •/p). ميانخين و انحراف معيار سنى افراد در زروه مداخله هـ/r / و در گروه كنترل

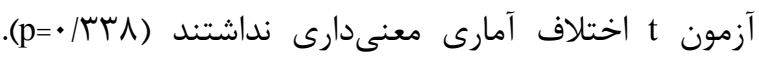
بيشتر افراد مورد بررسى در دو گروه خانهدار و متأهل بودند

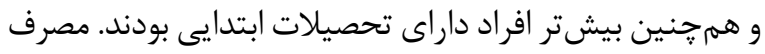

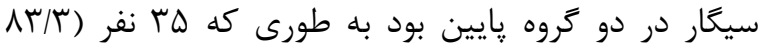

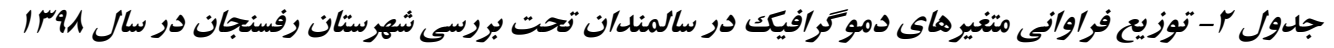

\begin{tabular}{|c|c|c|c|}
\hline مقدار p & (درصد) تعداد كنترل & (دروه مداخله & متغيرها \\
\hline
\end{tabular}

\begin{tabular}{|c|c|c|c|c|}
\hline & $\|(r g / T)$ & $\|(r g / r)$ & 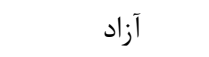 & \multirow{4}{*}{ 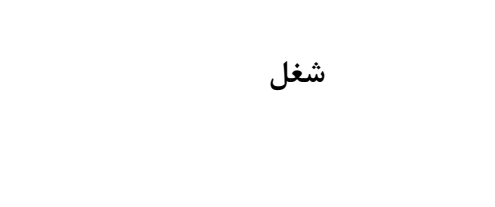 } \\
\hline \multirow[t]{3}{*}{$\cdot / 999$} & $1(T / \Psi)$ & $\cdot$ & كارتر & \\
\hline & $1 \cdot(\Gamma K / \Lambda)$ & $\|(T \& / T)$ & بازنشسته & \\
\hline & $Y \cdot(F \vee / Q)$ & $r \cdot(F V / q)$ & خانهدار & \\
\hline \multirow[t]{3}{*}{ •/VTA } & r & $r \wedge(q \cdot / \Delta)$ & متأهل & \multirow[t]{2}{*}{ وضعيت تأهل } \\
\hline & $\varphi(\mid F / Y)$ & $f(q / \Delta)$ & مطلقه و بيوه & \\
\hline & If $(r r / r)$ & $q(r \mid / F)$ & بىسواد & \multirow{4}{*}{ سطح تحصيلات } \\
\hline \multirow[t]{3}{*}{ •|GTT } & $Y)(\Delta \cdot)$ & $r \Delta(\Delta 9 / \Delta)$ & ابتدايى & \\
\hline & $F(9 / \Delta)$ & $9(1 f / r)$ & دييلم & \\
\hline & $r(V / r)$ & $r(r / \Lambda)$ & فوق دييلم & \\
\hline \multirow[t]{4}{*}{$\cdot / \uparrow \Delta \Lambda$} & & & & \\
\hline & $F(9 / \Delta)$ & $\Delta(11 / 9)$ & خوب ل & \multirow{3}{*}{ وضعيت اقتصادى-اجتماعى } \\
\hline & $r \Delta(\Delta q / \Delta)$ & $r q(99 / 1)$ & متوسط & \\
\hline & $\mid r(r \mid)$ & $\wedge(19)$ & ضعيف & \\
\hline \multirow[t]{2}{*}{$\cdot / 410$} & $1 \cdot(T r / \Lambda)$ & $V(\mid 9 / V)$ & بله & \multirow{2}{*}{ وضعيت مصرف سيعار } \\
\hline & rT (VG/T) & $r \Delta(\Lambda r / r)$ & خير & \\
\hline \multirow[t]{2}{*}{ • 1949} & $r q(99 / \cdot)$ & MI (VT/A) & 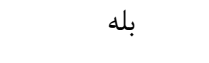 & \multirow{2}{*}{ ابتلاء به بيمارى زمينه اى } \\
\hline & $\|(T / \cdot)$ & $\|(T \& / T)$ & خير & \\
\hline & & & \multicolumn{2}{|c|}{ 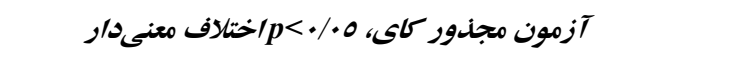 } \\
\hline & & 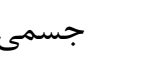 & 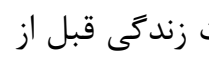 & نتايج بررسى تفاوت ميانخين نمرات كيف \\
\hline
\end{tabular}




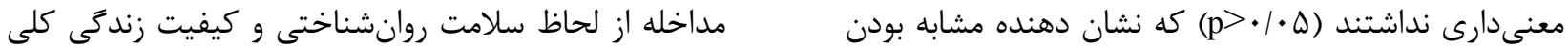

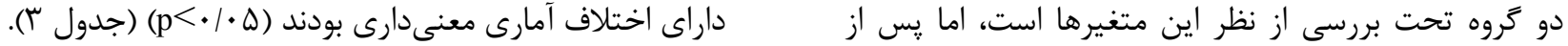

جلدول ب- مقاي سه ميانكين نمره خرده مقياسهاى كيفيت زندكى دو دو كروه قبل و بعلد از مداخله در سالمندان تحت برز سى شهر ستان رف سنجان در

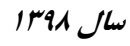

\begin{tabular}{|c|c|c|c|c|c|}
\hline \multirow{2}{*}{ مقدار p آزمون } & \multicolumn{2}{|c|}{ سه ماه بعد از مداخله } & \multicolumn{2}{|c|}{ ق قبل از مداخله } & \multirow[b]{2}{*}{ تروه } \\
\hline & 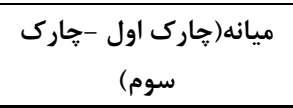 & $\begin{array}{l}\text { انحراف معيارد } \\
\text { ميانكين }\end{array}$ & 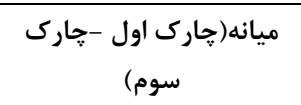 & انحراف معيارث ميانكين & \\
\hline L & $\Gamma T I / T \Delta(T \Delta G / T \Delta--T Y T / V \Delta)$ & $\Lambda g / r Y \pm r q \cdot / r F$ & $r \Delta \Delta / \cdot \cdot(|\Lambda \mathcal{G}| \Lambda \Lambda-r T \cdot / \cdot \cdot)$ & $\Lambda F / \| \varepsilon \pm r \Delta V / V F$ & \multirow{2}{*}{ سلامت جسمى } \\
\hline \multirow[t]{2}{*}{$\cdot / \mu \cdot \cdot$} & $r V Y / \Delta \cdot(|g| / / \Lambda \Lambda-r Y G / T \Delta)$ & $1.9 / 9 \Lambda \pm \Gamma \Delta \Gamma / \Delta \Delta$ & $r F \Delta / \cdot \cdot(\mid Q \cdot / \cdots-r T N / V \Delta)$ & $1 \cdot 1 / r \cdot \pm r r q / 1 V$ & \\
\hline & \multicolumn{3}{|c|}{.1 .99} & ( ) & مقدار p آزمون t مستقل "*" \\
\hline $.1 \cdot \cdot 1$ & $r q q / \Lambda r(r \cdot F / \Delta \cdot-r r q / V \Delta)$ & $r Y q / v \Delta \pm q q / 1$. & $r q \cdot / \Delta \Lambda(r) \cdot / \Delta \cdot-r q \mid / \Delta \cdot)$ & $r \Lambda \cdot / r q \pm q \cdot \mid q V$ & مداخله (זץ نفر) \\
\hline \multirow[t]{2}{*}{$\cdot / r q V$} & $r \mid Q / \cdots(T T F / T T-Y G T / T \Delta)$ & $r q \Psi / q \Gamma \pm \lambda r / r q$ & $r V q / \Delta \cdot(r / V / V \Delta-r \Delta \Lambda / V \Delta)$ & $r Y N / / F \pm q / / q V$ & كنترل (rF نفر) \\
\hline & & $1 . r \Delta$ & & .1914 & مقدار p آزمون t مستقل **" \\
\hline$\cdot / \cdot r$ & $r Y q / G T(T \Delta V / Q \Lambda-r q \Delta / V \Delta)$ & $r \cdot १ / ৭ 9 \pm \gamma / / r$ & $r G V / T \Delta(19 V / \Delta F-T r V / 19)$ & $r \varepsilon q / \cdot r \pm V q / / q$ & مداخله (Tץ نفر) \\
\hline$\cdot / 1 \Delta \Delta$ & $r q T / l r(r / V / r T-r \& q / r \Delta)$ & $T V F / \cdot 9 \pm \lambda V / T F$ & $r \Delta T / \Delta \cdot(\mid \Lambda T / F F-r r F / N \Delta)$ & $r \Delta \Lambda|\xi \Delta \pm \Lambda V / F|$ & كنترل (Tr ن نفر) \\
\hline
\end{tabular}

$\cdot / \cdot+4$

$\cdot / \Delta \mathrm{V} \cdot$

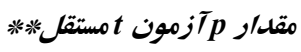

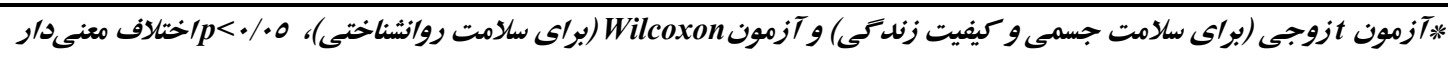
" Mann-withney U ( براى سلامت

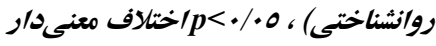

استفاده از آزمون t زوجى مقايسه شد و نتايج نشان داد كه ميانگين نمرات مربوط به كليه ابعاد به جزء سلامت عمومى در كروه مداخله به طور معنى دارى نسبت به قبل از آن افزايش يافته است (ه •/p>) در حالى كه اين افزايش در كروه كنترل

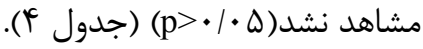

بررسى ابعاد كيفيت زندگى در گروه مداخله و كنترل نيز انجام شد. نتايج آزمون t مستقل نشان داد كه از بين ابعاد مربوط به كيفيت زندگى، نمره مربوط به درد، انرزى اخستگى و بهزيستى هيجانى بعد از مداخله در بين دو گروه داراى اختلاف آماى معنى دار هستند (ه • • p ). همرجنين ميانگين نمرات مربوط به ابعاد كيفيت زندگى درون گروهى نيز با

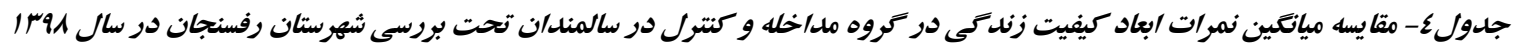

\begin{tabular}{|c|c|c|c|c|c|c|}
\hline \multirow[b]{2}{*}{ تى زوجى زقى } & \multicolumn{2}{|c|}{ سه ماه بعد از مداخله } & \multicolumn{2}{|c|}{ قبل از مداخله } & \multirow[b]{2}{*}{ 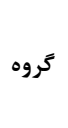 } & \multirow[b]{2}{*}{ 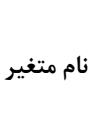 } \\
\hline & ميانه(جارك اول -جارك سوم) & 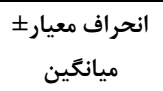 & ميانه(جارك اول -جارك سوم) & انحراف معيار 士 ميانكين & & \\
\hline . & $\Lambda \cdot / \cdot \cdot(\Delta \mathrm{V} / \Delta \cdot-q / / / \Delta)$ & $V T / T V \pm \Delta \cdot|9|$ & $V \Delta / \cdots(\Delta \cdot / \cdots-\Lambda \Delta / \cdot \cdot)$ & GV/TRIGT/VT & 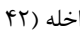 & \\
\hline
\end{tabular}

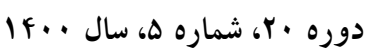
مجله دانشگاه علوم بزشكى رفسنجان 
.... تأثير آموزش شيوه زندگى سالم بر كيفيت زندگى سالمندان

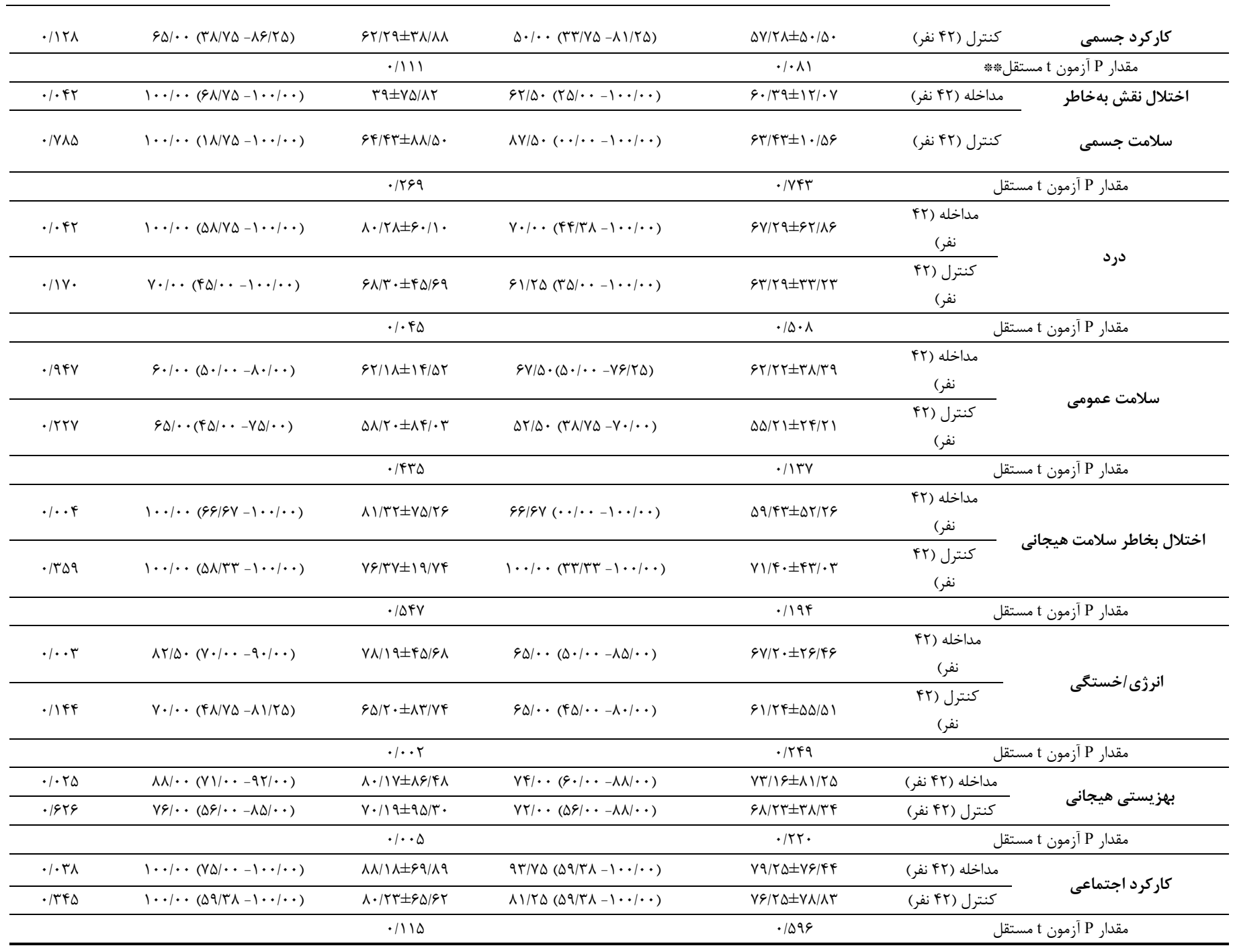

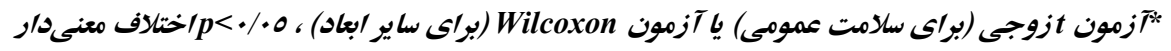

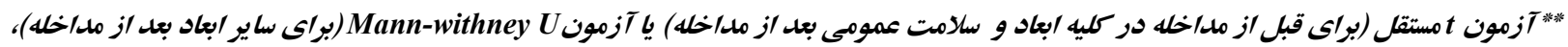

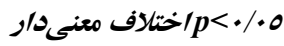

ارزيايى شد. براى بررسى پيش فرض همگنى واريانس (همكونى واريانسها در دو كروه مداخله و كنترل) نيز از

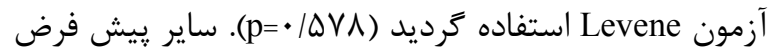
هاى مربوطه از قبيل برقرارى رابطه خطى بين نمره قبل از مداخله با متغير وابسته
به منظور مقايسه ميانگين نمره كلى كيفيت زندگى پس از مداخله، بعد از كنترل اثر يِيش از مداخله، از روش تحليل كوواريانس يك متغيره، بعد از بررسى ييش فرضهاى اين آزمون استفاده شد. نرمال بودن توزيع فراوانى نمره كلى كيفيت زندگى بعد از مداخله با استفاده از شاخصهاى جولنَى و كشيدگى و همجنين نمودار هيستوگرام براى هر گروه 
كه انجام مداخلات مربوط به افزايش كيفيت زندگى باعث (نمره بعد از مداخله) در هر دو گروه و عدم وجود داده يرت

بهبود كيفيت زندگى در افراد سالمند مىشود. همجنين

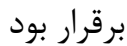
شاخص مجذور اتا نشان مى دهد كه مداخلات آموزشى تأثير همان كونه كه درجدول ه نشان داده شده است بعد از تقريباً متوسطى بر روى نمره كيفيت زندگى سالمندان دارد. كنترل اثر بيش از مداخله، نتايج آناليز كوواريانس نشان داد جلدول ه- نتايج آناليز كوواريانس جهت مقايسه ميانكين نمره كلى كيفيت زندكى بعلد از مداخله در دو كروه از سالمندان تحت بروسى در شهرسنان

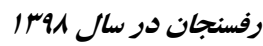

\begin{tabular}{|c|c|c|c|c|c|c|}
\hline مجذور اتا & Pقدار P P P & Fقدار F F F F F F & ميانغين مجذورات & درجه آزادى & مجموع مجذورات & منبع تغييرات \\
\hline$\cdot / \pi \Delta \cdot$ & $<\cdot / \cdot \cdot 1$ & $\kappa r / v$. & |NTrGG/IN & 1 & |NKTEY/IN & نمره كيفيت زندكى قبل از مداخله \\
\hline . $/ \cdot \Delta r$ &.$/ \cdot r V$ & $f / 4 q$ & $\mid M \Lambda r \varepsilon / 99$ & 1 & $|M \Lambda r G| \& 9$ & 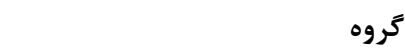 \\
\hline - & - & - & $4194 / 99$ & $\wedge 1$ & rॅ৭૬人ৎ/V৭ & خطا \\
\hline
\end{tabular}

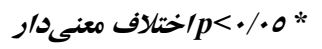

شناختى و كيفيت زندگى افراد گروه مداخله نسبت به قبل از بحث

مداخله داراى اختلاف معنىدارى بود ولى در زروه كنترل اختلاف معنى دارى مشاهده نشد. اين يافتهها به اين معناست كه آموزش شيوه زندگى سالم باعث ارتقاء كيفيت زندگى سالمندان در اين زمينه مىشود. در مطالعه حاضر مداخله آموزشى شيوه زندگى سالم شامل آموزش در خصوص تغذيه دوران سالمندى، بهداشت روان (بهداشت خواب، كنترل استرس) ورزشهاى دوران سالمندى و پِيش

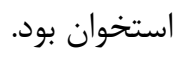
بررسى ابعاد كيفيت زندگى در گروه مداخله و كنترل انجام شد. نتايج نشان داد كه از بين ابعاد مربوط به كيفيت زندگى فقط انرزى/خستخى بعداز مداخله و بهزيستى هيجانى در بين دو گروه داراى اختلاف آماى معنىدار بودند. همرجنين فقط ميانگين نمرات مربوط به متغيرهاى درد و اختلال بهخاطر
سالمندى بخشى از فرآيند زيستى است كه تمام موجودات زنده از جمله انسان را شامل مىشود. با بهكارگيرى روشها و مراقبتهاى مناسب مىتوان تا حد زيادى از اختلالات و معلوليتهاى دوران سالمندى پيش گيرى كرد يا آن را به تعويق انداخت. در اين دوران وجود نيازهاى ويزه ممكن است كيفيت زندگى سالمند را تهديد كند. لذا، ارزيابى عوامل زمينهاى مؤثر بر ميزان كيفيت زندكى افراد در دوران سالمندى اهميتى انكارنايذير دارد [r/r]. نتايج مطالعه حاضر نشان داد كه دو كَروه از نظر متغيرهاى زمينهاى با هم همسان بودند و اختلاف معنىدارى بين دو كروه مشاهده نشد. يس از مداخله سلامت روانشناختى و كيفيت زندگى كلى داراى اختلاف آمارى معنىدارى بودند. همجزنين نشان داده شد كه سلامت جسمى، سلامت روان 
DFA تأثير آموزش شيوه زندگى سالم بر كيفيت زندگى سالمندان ...

كيفيت زندگى آنها مىشود. در مطالعه Sahebdel و همكاران به اين نتيجه رسيدند كه سالمندان ساكن آسايشگاه با توجه به اين كه كنترل كمى بر زندكى خود دارند و معمولاً درمانده مىشوند از اين رو بيشتر به استرس و افسردىى مبتلا مىشوند و از كيفيت زندگى پايينترى نسبت به ساير

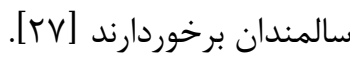
در اين مطالعه، روابط اجتماعى نيز معنى دار خزارش شد، به گَونهاى كه افزايش روابط اجتماعى باعث بهبود زندگى سالمندان مىشود. در مطالعه Khami و همكاران نتايج نشان داد كه روابط اجتماعى و حمايتهاى اجتماعى از جمله رفتارهاى ارتقاء دهنده سلامتى مىباشد [ب/] كه همسو با يافتههاى مطالعه حاضر است. در مطالعه Nikpour و همكاران نتايج نشان داد كه وجود حمايت اجتماعى باعث افزايش

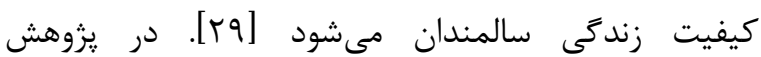
Grimmett دريافتند كه فعاليت جسمانى، با كيفيت زندگى سالمندان رابطه مثبت دارد در حالى كه رابطه سيخار كسيدن و كيفيت زندگى منفى است [بr]]. Heidari نيز در يزوهشى با عنوان بررسى تأثير برنامه آموزشى خود مراقبتى بر كيفيت زندگى سالمندان كه بر روى •ع نفر از سالمندان مراجعه كننده به مركز مراقبتى سالمندان اميد بروجن انجام شده بود، نشان دادند كه در تمام ابعاد كيفيت زندگى سالمندان يس از مداخله نسبت به قبل از آن افزايش يافته است [ع][]. در مطالعه Rugbeer
سلامت هيجانى يس از مداخله نسبت به قبل از آن داراى تفاوت آمارى معنىدارى بود. اين ارتباط مستقيم بين شيوه زندگى با كيفيت زندگى به نظر منطقى مىرسد، زيرا در فرآيند ״ير شدن علاوه بر كاهش سلامتى به دليل كهولت سن، عوامل مهرم ديخرى نيز تأثير گذار است، از جمله رعايت سبك زندگى سالم كه در افزايش اميد به زندگى، بهبود كيفيت زندكى و سلامت جسم و روان نقش تعيين كنندهاى ايفاء مىكند. هم

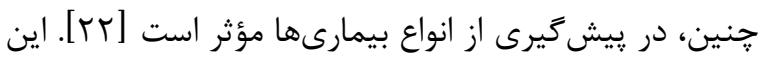
يافتهها با مطالعه Farhadi و همكاران كه به بررسى تأثير برنامههاى آموزش سبك زندگى سالم بر كيفيت زندگى

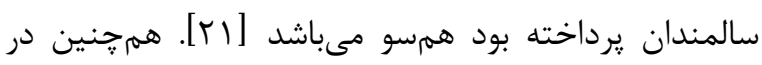
مطالعه Hekmatpour و همكاران كه به بررسى تأثير برنامهاى آموزشى سبك زندگى بر كيفيت زندگى سالمندان يرداخته بود [ع] و مطالعه Grimmett و همكاران همسو است [rr]]. به طور خلاصه، نتايج اين يزوهش و مقايسه آن با نتايج مطالعات ديگر نشان مىدهد كه سبك زندگى مهمترين تعيين كننده كيفيت زندگى در سالمندان است. در مطالعه حاضر سلامت روانى معنىدار ززارش شد، به نظر مى رسد كه سالم بودن سالمندان از نظر روحى و روانى باعث افزايش كيفيت زندگى آنان مىشود كه در مطالعات مختلف نيز به اين موضوع اشاره شده است، به طورى انجام فعاليتهاى ورزشى باعث بهبود كيفيت زندكى سالمندان مىشود [عץ-Yץ]] در تبيين اين يافته مىتوانيم بكوييم كه تنهايى و انزواى اجتماعى در سالمندان با كاهش سطح سلامتى جسمى و روانى ارتباط دارد كه در نهايت باعث كاهش 
جهت بررسى كيفيت زندگى به صورت كلى و براى عموم است קنانجه بتوان ابزار مرتبط با سالمندان و بر اساس فرهنگ ايرانى طراحى و استفاده كرد احتمالا نتايج دقيقترى خواهد

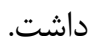

\section{نتيجه گيرى}

نتايج يزوهش حاضر نشان داد كه آموزش شيوه زندكى به سالمندان باعث بهبود سبك زندگى و به تبع آن افزايش كيفيت زندگى ايشان مىشود. بنابراين ضرورى بهنظر مىرسد در اولويت برنامههاى مسئولين در جهت حمايت از سالمندان

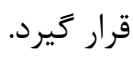
تشكر و قدردانى

اين يزوهش بخشى از يايان نامه كارشناسى ارشد رشته آموزش

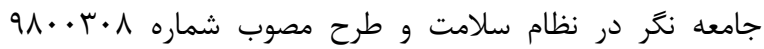

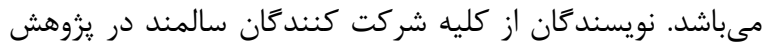

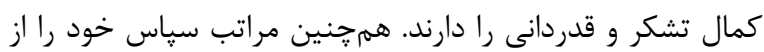

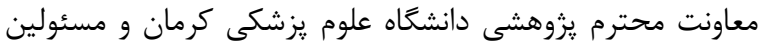

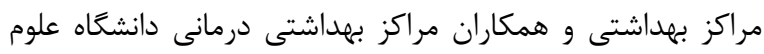
يزشكى رفسنجان اعلام مى دارند.

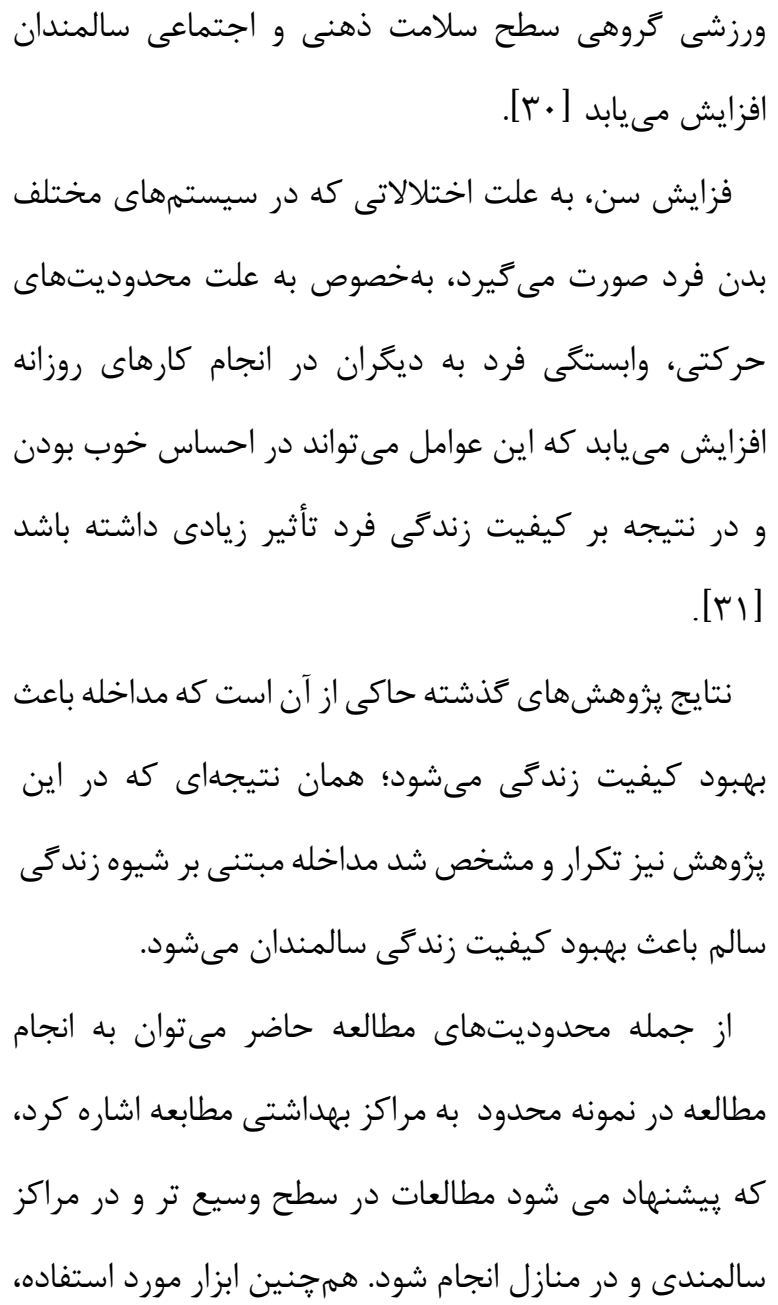

\section{References}

[1] Barsukov VN. From the demographic dividend to population ageing: world trends in the systemwide transition. Economic and Social Changes: Facts, Trends, Forecast 2019; 12(4): 167-82.

[2] Department of Economic and Social Affairs, Population Division. World Population Ageing 2017. New York:
United Nations. 2017. (ST/ESA/SER.A/408). https://www.un.org/en/development/desa/population/ publications/pdf/ageing/WPA2017_Highlights.pdf.

[3] Mehri N, Messkoub M, Kunkel S. Trends, determinants and the implications of population aging in Iran. Ageing Int 2020: 1-7. 
[4] Pakpour V, Zamanzadeh V, Salimi S, Farsiv A, Moghbeli G, Soheili A. The relationship between loneness and sleep quality in older adults in Tabriz. J Urmia Nurs Midwifery Facu 2017; 14(11): 906-17. [Farsi]

[5] Tel H, Tel H, Sabanciogullar S. Status of maintenance of activities of daily living and experience of loneliness infielder than 60 years old living at home and in institutions. Turkish J Geriatr 2006; 9(1): 34-40.

[6] Hekmatpour D, Shamsi M, Zamani M. The effect of healthy lifestyle educational programs on the quality of life of the elderly in Arak. J Arak Univ Med Sci 2013; 16(3): 1-11. [Farsi]

[7] Shahnazi H, Sobhani A, Cherkzi A. Relation of different aspects of lifestyle and elderly quality of life. $J$ Sabzevar Univ Meed Sci 2018; 25(3): 363-70. [Farsi]

[8] Abdollahi F, Mohammadpour RA. Health Related Quality of life among the Elderly Living in Nursing Home and Homes. J Mazandaran Univ Med Sci 2013; 23(104): 20-5. [Farsi]

[9] Montazeri A, Goshtasebi A, Vahdaninia M, Gandek B. The Short Form Health Survey (SF-36): Translation and validation study of the Iranian version. Quality of Life Res 2005; 14(3): 875-82.
[10] Tajvar M, Arab M, Montazeri A. Determinants of health-related quality of life in elderly in Tehran, Iran. BMC Public Health 2008; 8: 323.

[11] Rantanen, T., Hassandra, M., Pynnönen, K. et al. The effect of individualized, theory-based counselling intervention on active aging and quality of life among older people (the AGNES intervention study). Aging Clin Exp Res 2020. 32, 2081-90.

[12] Papathanasiou IV, Rammogianni A, Papagiannis D, Tsaras K, Kaberi F, Kontopoulou L, et al. Quality of life among elderly population. Glob Chall 2019; 2(2).

[13] Mohammadi Mehr M, Zamani-Alavijeh F, Hasanzadeh A, Fasihi T. Effect of healthy lifestyle educational programs on happiness and life satisfaction in the elderly: a randomized controlled trial study. Iran J Age 2019; 13(4): 440-51. [Farsi]

[14] Heidari M, Shahbazi S. Effect of Self-Care Training Program on Quality of Life of Elders. Iran J Nurs 2012; 25(75): 1-8. [Farsi]

[15] Shahnazi H, Sobhani A, Cherkzi A. Relation of different aspects of lifestyle and eldery quality of life. $J$ Sabzevar Univ Meed Sci 2018; 25(3): 363-70. [Farsi]

[16] Borzoo S, Arastoo A, Ghasemzade R, Zahednezhad S, Habibi A, Latifi SM. Effects of aerobic exercise on 
quality of life in residents of geriatric homes, Ahvaz, Iran. Iran J Ageing 2011; 6(1): 47-51.

[17] Khalili P, Vazirinejad RE, Jamalizadeh A, Nakhaee P, Fatehi F, Fallah A. The impact of healthy lifestyle education and integrated care on the quality of life of the elderly. J Occupational Health Epidemiol 2014; 3(2): 81-7.

[18] Ware Jr JE, Sherbourne CD. The MOS 36-item shortform health survey (SF-36). I. Conceptual framework and item selection. Med Care 1992; 30: 473-83.

[19] Montazeri A, Goshtasebi A, Vahdanian M, Gandek B. The short form health survey (SF-36): translation and validation study of the Iranian version. Quality Life Res 2005; 14(3): 875-82.

[20] Guide to living a healthy life style at an old age. Available from: https://aging.com/guide-to-living-ahealthy-lifestyle-at-an-old-age./

[21] Farhadi A, Foroughan M, Mohammadi F, Sahranavard M. The effect of healthy lifestyle educational program on rural elderly's quality of life in Dashti District of Boushehr Province. Salmand Iran J Ageing 2013; 8(3): 35-43. [Farsi]

[22] Habibi A, Neekpoor S, Seyedolshohda M, Haghani H. Health promotion behaviours and Quality of life among elderly people: A cross-sectional survey 2006. J Ardabil Univ Med Sci 2008; 8(1): 29-36. [Farsi]

[23] Grimmett C, Bridgewater J, Steptoe A, Wardle J. Lifestyle and quality of life in colorectal cancer survivors. Qual Life Res 2011; 20: 1237-45.

[24] Manzouri L, Babak A, Merasi M. The depression status of the elderly and its related factors in Isfahan in 2007. Salmand Iran J Ageing 2010; 4(4): 27-33. [Farsi]

[25] Barcelos-Ferreira R, YoshioNakano E, Steffens D, Bottino C. Quality of life and physical activity associated to lower prevalence of depression in community-dwelling elderly subjects from Sao Paulo. $J$ Affective Dis 2013; 150: 616-22.

[26] Hedayati M, Tabatabai S, MohammadiArya A, Robatjazi E, Lchinani F, Rostaie A. The efficacy of stress inoculation training upon the happiness rate and life's quality of old persons. J Sabzevar Univ Med Sci 2013; 20(2): 184-93. [Farsi]

[27] Sahebdel H, khoshkonesh A, pourebrahim T. Effects of group reality therapy on the mental health of elderly residing at Iran`s Shahid Hasheminejad nursing home. Salmand Iran J Ageing 2012; 7(24): 16-25. [Farsi]

[28] Khami L, Motalebi SA, Mohammadi F, Momeni M, Shahrokhi A. Can social support predict health- 
كQT تأثير آموزش شيوه زندگى سالم بر كيفيت زندگى سالمندان ...

promoting behaviors among community-dwelling older adults?. Social Health Behavior 2020; 3(1): 22.

[29] Nikpour S, Sola AH, Seiedoshohadaei M, Haghani H. Health promotion behaviors and quality of life among elderly in West area in Tehran-Iran 2006. ME-JAA 2006; 3(3): 3-7.

[30] Rugbeer N, Ramklass S, Mckune A, Van Heerden J. The effect of group exercise frequency on health related quality of life in institutionalized elderly. Pan African Med J 2017; 26: 1-14.

[31] Mellor D, Russo S, McCabe MP, Davison TE, George K. Depression training program for caregivers of elderly care recipients: Implementation and qualitative evaluation. J Gerontol Nurs 2008; 34(9): 8-15. 


\title{
The Effect of Healthy Lifestyle Education on the Quality of Life of the Elderly in Rafsanjan: A Quasi-Experimental Study
}

\author{
A. Sabbagh zadeh', R. Vaziri Nejad ${ }^{2}$, P. Khalili ${ }^{3}$, A.R. Doosti ${ }^{4}, \underline{\text { S. Sabzevari }}^{5}$ \\ Received: 22/06/20 Sent for Revision: 05/07/20 Received Revised Manuscript: 10/05/21 Accepted: 12/05/21
}

Background and Objectives: Education is always one of the ways to increase people's skills in life. Quality of life is also one of the most important issues in the life of people, especially the elderly. The purpose of this study was to investigate the effect of healthy lifestyle education on the quality of life of elderly people in Rafsanjan.

Materials and Methods: This research is a quasi-experimental study on elderly people. Using the multi-stage random sampling method, 84 elderly people were selected and randomly divided into intervention and control groups by random allocation method. In the intervention group, a 4-session training course was conducted to increase the quality of life, and no special action was taken in the control group. Using demographic information questionnaire and standard 36-item questionnaire, the quality of life of individuals in the two stages before and after the intervention was assessed. Data were analyzed using paired t-test, independent t-test, chi-square, and analysis of covariance (ANCOVA).

Results: The mean age of the patients in the intervention group was $64.26 \pm 3.05$ and in the control group $63.64 \pm 2.82$ which was not statistically significant $(\mathrm{p}=0.338)$. There was no statistically significant difference between the intervention and control groups before the intervention in terms of the studied variables $(p>0.05)$, but there was a significant difference in overall quality of life $(\mathrm{p}=0.037)$ after intervention so that the training intervention improved the elderly's quality of life.

Conclusion: According to the results of this study, teaching a healthy lifestyle to older people can improve their quality of life. Therefore, it should be a priority in the plans of the authorities.

Key words: Quality of life, Lifestyle, Intervention, Education, Elderly

Funding: The Vice-Chancellor for Research of Kerman University of Medical Sciences provided a part of the project cost in the form of research grants.

Conflict of interest: None declared.

Ethical approval: The Ethics Committee of Kerman University of Medical Sciences approved the study (IR.KMU.REC.1398.265).

How to cite this article: Sabbagh zadeh A, Vaziri Nejad R, Khalili P, AliDoosti A, Sabzevari S. The Effect of Healthy Lifestyle Education on the Quality of Life of the Elderly in Rafsanjan: A Quasi-Experimental Study. J Rafsanjan Univ Med Sci 2021; 20 (5): 539-53. [Farsi]

1- MSc Student in Community Education in Health System, Dept. of Medical Education, Center for Studies and Development of Medical Education, Kerman University of Medical Sciences, Kerman, Iran, ORCID: 0000-0003-0163-4147

2- Prof., Dept. of Epidemiology and Biostatistics, Social Determinants of Health Research Centre, Rafsanjan University of Medical Sciences, Rafsanjan, Iran, ORCID: 0000-0002-1978-0946

3-PhD Student in Epidemiology, Dept. of Epidemiology and Biostatistics, Social Determinants of Health Research Centre, Rafsanjan University of Medical Sciences, Rafsanjan, Iran, ORCID: 0000-0002-0486-934X

4 General Physician, Vice-Chancellor for Health, Health Systems Research Center, Rafsanjan University of Medical Sciences, Rafsanjan, Iran, ORCID: 0000-0002-0024-9370

5-Associate Prof., Dept. of Medical Education, Center for the Study and Development of Medical Education, Kerman University of Medical Sciences, Kerman, Iran, ORCID: 0000-0002-9021-7101

(Corresponding Author) Tel: (034) 31325219, Fax: (034) 31325218, E-mail: s_sabzevari@kmu.ac.ir 